\title{
The modern monastic Santmat movement of Bihar: building bridges between Sanātana Dharma and Sant-Mat
}

Veena R. Howard

Correspondence: vehoward@csufresno.edu California State University, Fresno, USA

\begin{abstract}
This article analyzes how the modern movement of Santmat, literally "the views of sants," primarily popular in the rural areas of northern India, uniquely situates itself within the context of "Vedic Dharma." Through the monastic leadership's redefinition of the categories of Vedic Dharma and Sanātana Dharma, the Santmat tradition creates a space where vernacular Hindu practices and mystical Vedic paths can co-exist. Thus, it stands apart from other contemporary Sant Mat traditions that reject Vedic Dharma. In this article, I pair an examination and analysis of the Santmat movement's historical development and methods, in which Vedic wisdom coheres with the sants' spiritual insights, with an ethnographic analysis of how this movement enacts a creative integration of vernacular traditions. I suggest that this particular Santmat's "bricolage," to borrow a term from Claude Levi-Strauss, illustrates a distinctive example of experimental dharmas in the context of vernacular sant traditions in contemporary North India. Santmat's skillful integration of local religious vernaculars gives expression to its engagement with lived devotional traditions. Such mixing of practices, which illustrate the processes of hybridity and syncretism, has helped to make the esoteric practices more meaningful and relevant to the everyday lives of the masses, including the tribal and rural people of Bihar and Nepal, populations often marginalized in orthodox Hindu practices. I examine the experimentation occurring within the Santmat tradition and argue that Bihar's Santmat movement may be termed "Vernacular Vedic Dharma." Furthermore, I address how within the $21^{\text {st }}$-century rise of extremism, Santmat shows that Vedic Dharma, within its manifold strands of practices and philosophies, encourages an adherence to the harmonizing esoteric spiritual path as well as a universal ethical framework.
\end{abstract}

The modern movement of Santmat, literally the "teachings" or "views" of sants (saints), is primarily popular in the rural areas of Bihar, Uttar Pradesh, and Nepal. ${ }^{1}$ While sharing essential elements with the Sant traditions of India (including Rādhāsoāmi), specifically the inner path of Divine Light and Sound for direct experience of the Divine, this branch situates itself within the context of "Vedic Dharma." It is through redefining the categories of Vedic Dharma and Sanātana Dharma that the Santmat tradition opens up a space where vernacular Hindu practices and mystical Vedic paths can co-exist.

The spiritual teachers of the modern Santmat tradition uniquely define "Vedic Dharma" as a "Wisdom Tradition," whereas "Sanātana Dharma" is described as the "path that unites with the Eternal (sanātana) Truth, Supreme Being."3 By defining it in

(c) The Author(s). 2017 Open Access This article is distributed under the terms of the Creative Commons Attribution 4.0 International License (http://creativecommons.org/licenses/by/4.0/), which permits unrestricted use, distribution, and reproduction in any medium, provided you give appropriate credit to the original author(s) and the source, provide a link to the Creative Commons license, and indicate if changes were made. 
this way, Santmat embraces the wisdom of the tradition while simultaneously rejecting the concepts, such as discrimination based on caste and gender, as well as Hindu practices. Importantly, the Santmat tradition does not represent Vedic Dharma or Sanātana Dharma simply as Hinduism, but rather as systems of divine knowledge. In this article, I pair an historical examination of the Santmat movement's development and methods which suggest coherence between Vedic wisdom and sants' spiritual insights with an ethnographic analysis of the creative integration of vernacular traditions enacted by this movement. I contend that this particular Santmat's "bricolage," to borrow a term from the anthropologist Levi-Strauss (1966), illustrates a distinctive example of experimental dharmas in the context of sant traditions in contemporary North India. ${ }^{4}$ I draw on the Sanskrit term prayoga for the current use of "experimental." Prayoga literally means "application," and is generally translated as "experiment." It implies an integral connection with "investigation into truth" and "living the truth," as was used by Mahatma Gandhi (see: Howard 2013, 39). Santmat tradition emphasizes the path of inner journey to the realization of truth as well the practice of ethical codes of abstaining from lying, stealing, intoxicating substances, etc.

The Santmat tradition's skillful incorporation of local religious vernacular languages and practices gives expression to its engaging lived devotional traditions with which to reimagine its conceptual boundaries in a transnational age of plurality, heightened selfcritique, and rapid social change. Blending regional religiosity in connection with rituals-such as offering flowers to the Guru, touching the Guru's feet, worshiping the image of the Guru, singing songs in vernacular languages (i.e., Bihari and other regional dialects of rural communities), and big carnival and cavalcade-like ceremonies-with a focus on esoteric meditation that I further suggest has no parallel in any other SantMat traditions that emerged in northern India since the early $19^{\text {th }}$ century. I contend that such mixing of practices, which illustrate the processes of hybridity and syncretism, which the other contributors to this volume spotlight as defining characteristics of experimental religion as lived in the current global milieu of the $21^{\text {st }}$ century, has helped to make the esoteric practices more meaningful and relevant to the everyday lives of the masses, including tribal and rural people of Bihar and Nepal, who are normally marginalized in orthodox (Brahmanical) Hindu practices (cf. McGuire 2008). Experimenting with the religious boundaries of Santmat to include typically underprivileged caste and ethnic groups, and by implication their local religiosities, makes it possible for this Santmat movement to widen its appeal and meet the challenges of modernity.

On the basis of the experimentation occurring within the Santmat tradition discussed here, I argue that Bihar's Santmat movement may be termed "Vernacular Vedic Dharma," and in doing so, I draw on Leonard Norman Primiano's helpful coining of "vernacular religion" (1993). According to Primiano, "Vernacular religion is, by definition, religion as it is lived: as human beings encounter, understand, interpret, and practice it" (1993:44). The Santmat movement's interface with local-and often overlooked-Hindu practices in Bihar gives rise to a "Vernacular Vedic Dharma," a tradition not seeking to dissociate itself from Vedic tradition, but instead wanting to situate within it. This claim calls attention to the ways in which Vedic Dharma as imagined in textual discourse becomes embodied and, in turn, actualized in the local by means of the relationships that practitioners create together and with the powers they imagine to be sacred (cf. Orsi 2012). To that extent, this paper explores how the Bihar Santmat movement carefully selects texts and 
reinterprets the grammar of symbols embedded in the philosophical writings and myths of Hindu Dharma, in order to align the movement with shared understandings of the medieval Sant tradition's esoteric teachings. Such interpretation is aimed at three objectives: 1) to trace the roots of Sant traditions in Hindu Dharma by showing the link between the two, which has been dismissed by sants and scholars alike; 2) to use the common religious language of symbols to communicate an esoteric spiritual path to the impoverished and non-literate masses of rural areas, consisting of populations steeped in lived Hindu religiosities and myths, in which the ordinary "counts" as extraordinary; and finally, 3) to address the contemporary rise of extremism within India by showing how the Vedic Dharma within its manifold strands of practices and philosophies encourages an adherence to the harmonizing spiritual inner path of Divine Light and Sound as well as an ethical framework. Santmat of Bihar's reading of Vedic Dharma renders an image of the tradition that is pluralistic and includes both esoteric spiritual paths and rural religiosities. Santmat's openness to experimenting with its definitional boundaries by constructing itself as "Vedic Dharma" is unique; because of its monastic leadership, not bound by clans and lineages, it distinguishes itself from other contemporary Sant Mat traditions. Historically, the monastic system of India suggests that the boundaries of caste and ethnic distinctions are transcended by participation in renunciation (sannyāsa). Renouncers, ideally, leave behind the social distinctions of caste, class, and educational status. They represent an elite religious authority and have helped to reconfigure the conventional parameters of Hinduisms in South Asia and the Diaspora (cf. DeNapoli this volume). This pattern is seen in various strands within Vedic Dharma. Santmat of Bihar has been able to broaden its scope to include the everyday worlds of villagers and tribal people, the majority of whom are uneducated, and continue the Sant traditions' nonalliance to any particular religious group and propensities for social reform, which are the foundational ideals of the Hindu renouncer traditions within which Santmat of Bihar locates itself.

\section{Background: medieval Sant-Mat traditions and modern Santmat movements-a brief historical analysis}

Various adaptations of and resistance to hegemonic (orthodox and extremist) belief systems-e.g., those found within Hinduism, Islam, and Sikhism-in modern Santmat movements have their roots in medieval Sant traditions. ${ }^{5}$ In Hindus: Their Religious Beliefs and Practices, Lipner (2010) employs the term "Sant-Mat" to describe the medieval Sant tradition that confronted and challenged the dominant views of caste- and purity-based hierarchies. He says,

Before the advent of modernity, there was an influential vernacular 'movement', or more properly, a swelling mood, that attacked the privileges and discriminations of caste 'from below', that is, from a popular base among ordinary people. This has been called Sant-Mat, the View of the Sants or poet-saints, who became prominent in a broad arc from east to west mostly in the central and northern regions of the subcontinent from about the late thirteenth century (Lipner 2010:129).

As Lipner describes, these critiques of privilege came "from below." This detail highlights how the sants ' privileging of vernacular religion, which included women and lower 
castes, for whom personal experience-the basis of experimentation-provided the means for claiming religio-spiritual authority in patriarchal religious societies. ${ }^{6}$ Certainly, as evidenced by the history of the medieval sant traditions, "vernacular" is the defining trait of Sant-Mat (which can also be found in other sects of religious traditions of India). However, anchoring itself within the wisdom of the Upanișads and emphasizing subjective experience of meditative states is unique to the Bihar's Santmat. Lipner rightly argues that Sant-Mat was "not a homogenous trend," but rather encompassed general tendencies, including rejection of caste-based segregation, sectarianism, and veneration of images. These tendencies illustrate the central belief of the Santmat movement, which "reckon[s] true religion as a matter of the will and heart, rather than of birth, theology, and ritual" (Lipner 2010: 130). Lipner identifies that the religion is connected to "will and heart," and not to outside social or political forces. He also underscores the harmonizing qualities of "Sant-Mat," which are reflected in the modern branches of Santmat. The tradition's emphasis on "will and heart" is significant because it indexes the medieval Sant-Mat's ascription of importance to the personal dimensions of religiosity and suggests that experimentation involves combining the empirical "truths" of objective reality with the inner wisdom of subjective experience. Lipner's account of "Sant-Mat" gives a broad overview of the Sant traditions that emerged in the era of cultural interface among Hindus, Muslims, and the newly formed Sikh tradition. In the $20^{\text {th }}$ century, spiritual movements that shared the ideology of the path of Divine Light and Sound identified themselves under the broad category of "Sant Mat," although they had variations in theoretical and ritualistic conventions.

Published two decades before Lipner's exploration, Schomer and McLeod (1987) coedited volume, The Sants: Studies in a Devotional Tradition of India, provides a comprehensive survey of various Sant movements, sub-sects, and modern subsidiary revivals of the sants' teachings. These studies make it clear that the term "Santmat" has become an overarching idea within which various sects are included. These sects are derived from the "clan and lineages" of different sants, such as Kabir Panth, Dadu Panth, Daria Panth, and Rādhāsoāmi Mat (cf. Gold 1987). These studies also accentuate that Sant traditions are diverse and cannot be monolithically defined. Schomer and McLeod further point out that variances emerge in the recent Santmat movements. Be that as it may, what has been missed in these studies is the articulation of the experimental character of these devotional traditions. The analytic of experimentation becomes even more visible in the monastic movement of Bihar. I argue that due to its monastic leadership, Santmat of Bihar is able to produce voluminous literature, bridging theology and meditation paths of Hinduism and sant traditions and emphasizing that inner mystical experiences are accessible by all, irrespective of caste, gender, and creed. Historically, the Indian ideal of monasticism, by its very nature, allows the renouncer to question the significance of caste, ethnic, and gendered identities, which the Bihar's Santmat carries forth in its challenge to religious factionalism and still prevalent caste biases in the rural areas of Bihar. ${ }^{7}$

By virtue of its unique monastic leadership, Santmat of Bihar negotiates both acceptance of select ideologies of dharma and rejection of religious factionalism and extremism, and most importantly, in its inclusion of the non-literate religious vernaculars. Its identification with Sanātana Dharma, sets it apart from other modern sant traditions. For example, Rādhāsoāmi Mat, which has been studied by scholars and shares roots with 
Santmat, carries on the tradition of harmony and unity while still maintaining a lineagebased identity. ${ }^{8}$ In his research on the modern Rādhāsoamī movement, Juergensmeyer (1987) shows its connections between the teachings of sants like Kabir, Dadu, and Nanak, but at the same time he calls attention to its unique elements, including "the inner path of spirituality," "necessity of Guru," and "the fellowship of Satsang." Juergensmeyer also underscores that "the term religion (dharma) is avoided by the movement in describing itself." ${ }^{\prime 10}$ Perhaps this reluctance stems from a desire to maintain its tradition as a spiritual path, since avoiding the category of "religion" supports the focus on a path that can be practiced by anyone irrespective of their religious affiliation. The fact the he avoids the use of the term "dharma" is also true in terms of other contemporary sant movements, such as Ruhani Satsang of Kirpal Singh Ji Maharaj (1894-1974), which share a history, lineage, and the inner path of spirituality of Divine Light and Sound with Rādhāsoamī traditions. However, the monastic branch of Santmat of Bihar also traces its origins back to Sant Tulsi Sahib. It uniquely describes Santmat as "Vedic Dharma," thereby recognizing it as a religion (more precisely "dharma") while still maintaining the inclusivity of the sant tradition. ${ }^{11}$

Thus, the Santmat tradition indicates an understanding of dharma as inherently experimental in the context of experiencing the inner mystical world while simultaneously using subjective truth to reassess the nature of objective reality. Moreover, this tradition continues to keep the nomenclature of Santmat, unlike other popular recent movements like Rādhāsoamī Mat that assert their distinct identity. Historically sants rejected the normative religious prescriptive laws and dogma. But Santmat of Bihar renders dharma consistent with a harmonious vision of the society on the basis of the experimental nature of dharma. It challenges the religious factionalism that has spread across the dharma traditions in the name of constructing an authentic dharma. This objective reality is challenged by the Santmat on the basis of experience that subjective truths reveal the divinity of all beings, regardless of caste, status, or gender.

The 20th-century leader of the monastic Santmat, Maharshi Mehi (1885-1986), who was born in a village in Bihar and chose a monastic life in his youth, is the catalyst for redefining Santmat in the modern period. He maintained Santmat was not affiliated with any particular religious sect and its path can be practiced by followers of any religion, a claim that he made on the basis of his own spiritual experiences. Through a careful study of the texts of various traditions, he defined dharma not as "religion" but as the path to unite with the Divine. Maharshi Mehi also simultaneously systematically defined Santmat and showed the path and teachings of Santmat as having roots in the texts of Hindu Dharma while maintaining the universal presence of the path in all great religions of the world. His methodology of personal experimentation with the truths of dharma affirms the experimental nature of dharma. It becomes evident that the experimentation occurs when the practitioner negotiates the inner/spiritual with the outer/ material/intersubjective. ${ }^{12}$

Based on the developments highlighted above, I argue that the Santmat tradition of Bihar aims to build bridges among Hindu Dharma, teachings of Sant traditions, and other religious traditions. In doing so, the scope of Santmat practice-namely the ethical principles, daily religiosity, meditation, and path-is reimagined to include the tribal people and the masses of the rural areas of Bihar, Uttar Pradesh, and Nepal, areas that culturally and religiously relate to vernacular Hindu religiosities. Consequently, the 
experimentation that takes place within the Santmat tradition makes it possible to engage and make meaningful sense of the contemporary challenges posed by globalization and the changing landscape of religion in India. For the purpose of making the reader aware of the specific methods that the Bihar Santmat uses to craft itself as "Vedic Dharma," we will explore the ways that this modern movement systematically begins with defining the root categories of "sant" and "santmat." It is to this task that I now turn.

\section{Santmat redefined}

Although generally more popular in rural areas of northern India and Nepal, the monastic Sant tradition is not a simplified version of the Sant Tradition. Rather it shows a sophisticated and systematic link between the teachings of the sants with Sanātana Dharma. By examining the many volumes of writings published by Maharshi Mehi and his many spiritual successors-including Swami Santsevi Ji Maharaj and Swami Vyasanand Ji Maharaj-the depth and breadth of the integration of Vedic wisdom with sant teachings, and by implication the experimental patterns of this Santmat, become evident. Furthermore, sants of the tradition provide extremely detailed, serious guidance for spiritual seekers and devotees on the path. For this, the tradition systematically engages with the taxonomies of both the sant tradition and Sanātana Dharma.

Historically, the terms sant and saint are used interchangeably, and it is difficult to find a text that succinctly defines "sant" and "santmat." In his book Mokșa Darsana, Maharshi Mehi provides a copious definition:

1. Stillness or steadiness is the essence of Śanti [absolute peace; unity with the Divine]. ${ }^{13}$

2. Those who have attained śanti are sants. ${ }^{14}$

3. Santmat encompasses the thoughts and way (mat) of sants.

4. It is natural for human beings to desire śanti. Inspired by this inherent desire, seers of ancient times searched for the inner peace and found the path to attain it. This path has been expounded in the Upanișads. ${ }^{15}$ Similar views have been expressed by more recent sants such as Guru Nanak and Kabir Sahab, etc. They expressed their views in Punjabi and Hindi vernaculars. ${ }^{16}$ Such expressions are for the inspiration and edification of people at large. The teachings of these later sants are what are referred to as Santmat. ${ }^{17}$

For Maharshi Mehi, "the Upanișads must be considered the foundation of Santmat, because they uniquely and copiously elucidate on the means for attaining śanti." Drawing on the later Upanișads such as Nadabindopanișad, Sandilayopanișad, Dhyanbindopanișad, and Yogshikhopanișad, he argues that "the Upanișads explain the yogic techniques and systematic views of transcending mind and attaining the Absolute through the path of Divine Sound (Yoga of Surat-Shabd)." ${ }^{18}$ It is significant that Maharshi Mehi invokes the Upanișads to represent this vision of Santmat, because these teachings often depict inner wisdom as the true source for constructing the outer reality of lived dharma. That is, the mysticism illustrative of the Upanișads showcases dharma as experimental par excellence.

Not only does Maharshi Mehi locate the path of Santmat in the Vedānta literature, but he also establishes the underlying unity among the teachings of the sants, saying, 
Often the teachings of various sants would, on the surface, seem contradictory to each other or even contradictory to the principles of the Upanișads. However, there is an unbreakable unity in the spiritual views of all sants. In different times and in different places sants appear, and their followers name their tradition after the particular saint. ${ }^{19}$

According to Maharshi Mehi the apparent differences among the teachings of sants can be attributed to the variation of regional languages and traditions. He narrows down the root of such disparities: "It also happens that excessively zealous followers of Santmat accentuate the differences." So despite the apparent differences, he concludes that there is unity in the teachings of sants: "When all sectarianism and the external differences in the teachings of a sant are removed, the basic principles of Santmat are in unity." ${ }^{20}$ Maharshi Mehi pushes unity on the basis of his personal mystical experiences that are analogous to the illustrations of experiences across traditions. While this argument and deductive reasoning might appear to be an effort to create a sense of homogeneity in the teachings of various sants, Maharshi Mehi invited his followers and opponents alike to experiment with the experience of the truth within which the hubris of factionalism fades way. This is the reason he preferred the inclusive category "santmat" for the tradition.

The principles of Santmat read like a Magna Carta, as it were, as they form the theoretical foundation for the monastic movement of Santmat. By defining the categories of both "sant" and "santmat," Maharshi sets up a framework for harmonizing the teachings of sants and understanding the connection between the ancient Vedānta wisdom and later teachings of sant traditions. It opens up a space for the masses who identify themselves with Hindu traditions to experiment with the definitional boundaries of dharma. In praxis, the principles of Santmat are considered so essential for both monastic and lay followers (who belong to various castes, social, and economic standings) of the tradition that ritual recitation of the entire set of principles is incorporated in the daily regimen of practice, along with three times of daily meditation and singing of devotional bhajans of various sants. Such praxis emphasizes the unity in principle and interrogates sectarianism. Simultaneously, it allows the path to be integrated with regional Hindu practices, yet defying Hindu rituals and caste-based rules. Each morning, devotees, who might be non-literate but have memorized the principles, recite in unison the principles of Santmat along with a set of prayer songs. ${ }^{21}$ This is a testament to the crucial role that Maharshi Mehi's definition plays in Santmat ritual and practice.

Even after Maharshi Mehi's passing in 1986, many monks independently continue to impart the teachings of Santmat in various regions of India and experiment with the interpretations of his teachings as seen in their inclusion of lived religions. At the same time, each sub-branch continues to identify itself as "santmat," despite minor variations in following the path. These sub-branches, which are united by the common Guru Maharshi Mehi, emphasize the four principles of Santmat as articulated by the Guru: 1) Guru (importance of a guru who has experienced Divine Light and Sound within); 2) Dhyāna (mediation at least three times a day); 3) Satsang (listening to the teaching of sants and inner contemplation); and 4) Sadācār (moral conduct, abstaining from five vices, lying, stealing, intoxicating substances, violence, and sexual misconduct). All of these principles are shown to be present in the texts of Vedic Dharma, including the 
Rāmāyana and the Bhagavad-Gittā. Through its leadership of sannyāsīs, the tradition affirms the integral relationship between Santmat and Vedic Dharma; it situates itself within the broader scope of the wisdom of Sanātana Dharma, which was defined by Maharshi Mehi as a philosophy of Truth that can be accessed through the inner path of meditation.

The connection between Santmat and Vedic Dharma is emphasized even more by the new generation of monks, for whom experimentation invites a new meaning in the context of including and valorizing the vernacular. Perhaps this emphasis is due to the religious sensibilities of the followers who are primarily from rural areas and tribal traditions. During my last visit to India, I asked the following of a contemporary guru: how do you explain the relationship between Vedic Dharma and Santmat? How are the terms "Vedic Dharma" and "Sanātana Dharma" defined in Santmat? He told me that Santmat sees Vedic Dharma distinctly—not as the religion of Hindus, but rather as "the path of Divine Wisdom." In the same vein, he defined Sanātana Dharma as "the path that unites humans to the Sanātana (Eternal) Supreme Being," not as traditional Hinduism with certain religious structures. ${ }^{22}$

Thus, both terms that are used for Hinduism were rendered into signifying a spiritual path, and not a religion with an exclusive dogma. However, public gatherings are increasingly becoming rife with Hindu symbols combined with dazzling display of various sants' photos. While these developing definitions and public performances might appear to be a step toward "Hinduisation" of a movement, I suggest that this reinterpretation is aimed at reforming Hinduism's emerging sectarian sentiments-which in the recent past has led to bigotry and discrimination of non-Hindu groups in India-and reaching out to the masses that seek familiar representations. Monks in the tradition continue to hold on to the identity of the movement with the generic designation of "santmat" and negotiate the boundaries between Hinduism and the Sant tradition. Nevertheless, the monastic leadership and use of symbols present a prima facie view of Hinduism.

\section{Monastic Santmat tradition: bridging the boundaries between Sanātana dharma and Sant traditions}

According to Lorenzen (2011), "Religious identities are also religious boundaries. How we define our own religious identity depends on defining who we are not. If we are Hindus, then we are not Muslims, Christians, Buddhists, or Sikhs" (2011: 19). In the context of Santmat, the question of identity is crucial. Since the turn of the millennium and the widening divide among religious groups, the modern monastic movement of Santmat has begun to experiment with how it defines itself in the current global age. It continues to use the term "santmat" despite some differences with other Sant traditions of the $18^{\text {th }}$ century colonial period. Notwithstanding the urge to define separate religious identity (as Lorenzen points out), Santmat continues to define itself by widening the circle-not by defining "what it is not." Of course, in doing so, Santmat maintains its identity as a spiritual tradition with certain practices and prohibitions.

Notice that by expanding its conventional definitional identity, Santmat communicates experimental dharma in this tradition. It recognizes sants, religious leaders, and prophets, such as Kabir, Shri Ramakrishna, Ramana Maharshi, Lord Mahavira, the Buddha, Lord Krishna, Lord Rama, Jesus Christ, Sufi mystics, and Guru Nanak, as 
seekers of Truth having practiced the inner path of Divine and Light and Divine Sound in order to attain spiritual liberation or unity with the Supreme. Simultaneously, the tradition affirms both lay and monastic practitioners' inherent ability-irrespective of caste, ethnicity, and gender-to experience the inner truths through the initiation into the meditation of Divine Light and Divine Sound. It is intriguing to witness how female followers of the tradition, who might live in the gendered world of social constraints, equally participate in the inner world of spiritual experiences. Thus, the circle of experimentation continues through teachings and experiences.

At the same time, Santmat affirms the often-overlooked connection between Sanātana Dharma and Santmat. Various teachers of the tradition systematically analyze Hindu texts (Rāmàyaṇa, Mahäbharata, and Purānas) to show the four principles of Santmat integral to the Vedic Dharma or Sanātana Dharma. Mahrishi Mehi extrapolates the mystical essence of Hindu texts while simultaneously rejecting the dogma and rigid customs of Hinduism. In an interview James Bean, who has been involved with the study of various Sant traditions, surmises:

Maharshi Mehi Paramhans and other Sants of India have been in the cultural context of Hinduism what Sufis, Gnostics, and Christian Mystics have often done in relation to their respective traditions: focusing on the esoteric passages contained in their scriptures. They find mystic jewels or gold embedded in the "mud" of tradition, including references to the all-loving God beyond space, form and ritual. While not paying much homage to institutions or outer temples made of wood and stone, they make the heart of their message a contemplative meditation practice that promotes the exploration of inner space in the "temple" of the human body. ${ }^{23}$

While Santmat does not promote the conventional rituals of any tradition, some of the ceremonial practices have organically become incorporated in the tradition. This conflation of the traditions has given rise to a hybrid religiosity, in which ambiguity, power, and creativity shape interpretations of religious experience and "tradition." In a recent analysis, Primiano (2012) underscores these characteristics as dimensions of global religious vernaculars. ${ }^{24}$

In both theory and practice, the teachers of Santmat negotiate boundaries between the principles of Santmat and Sanātana Dharma. While the theory of Santmat is not confined to any particular religion, its public language of performance is consistent with the regional flavor of "Vedic Dharma." The conventional forms of Santmat's praxis-including satsang (listening to the discourse of the guru) and dhyanna (meditation)-have become integrated with the Hindu form of kathä (Hindu religious story-telling), and practice of establishing a mürtì (a life-sized image of the Guru). This modification in praxis raises questions about the relationship between the center (Hinduism) and the periphery (Sant traditions) in experimental contexts. I claim that the monastic nature of Santmat of Bihar allows it to stay situated on the margins of Hinduism while remaining anchored in the broader vision of Sant tradition that defies alliance to any particular religion. The ability to remain connected to both Hinduism and Sant tradition is due to the Santmat's monastic leadership. A monastic who renounces the bonds of the society is free to experiment and, therefore, to transform the interpretation and application of religious systems. The ochre robes, the symbol of sannyāsa, signify "freedom" for a higher purpose, and 
sannyāsis are seen as the representatives of Hindu dharmas. A shared structure of symbols is what grounds them in Sanātana Dharma, even as they play with the malleable boundaries of their religious tradition, which is characteristic of Santmat of Bihar.

A monastic who steps outside of society proper may even become a catalyst for social reform and a "dynamic center of religious development and change." Dumont (1970) says,

Is it really too adventurous to say that the agent of development in Indian religion and speculation, the 'creator of values', has been the renouncer? The Brahman, as a scholar, has mainly preserved, aggregated, and combined; he may well have created and developed special branches of knowledge. Not only the founding of sects and their maintenance, but the major ideas, the 'inventions' are due to the renouncer whose unique position gave him a sort of monopoly for putting everything in question (Dumont 1970: 46).

We may understand that the change which the renouncer-monastic brings to religion is illustrative of the fundamental characteristic of experimentation in the Dharma traditions of South Asia. ${ }^{25}$ Born into a non-Brahmin family, Maharshi Mehi, to use the Dumont's phrase, exemplifies an "agent of development" and models experimentation in the Dharma traditions. He acquired the status of a sant on account of his sannyāsi lifestyle, long periods of sädhana, and vows of renunciation. He argued that sannyāsis must not be beggars, but rather self-supporting individuals. This is consistent with the lives of Sants such as Kabir and Ravidas, who earned their living through the meager jobs of weaver and cobbler, respectively. Mehi, who had left his home and schooling in search for the Divine, was loaned money from his Guru Baba Devi Sahib (who himself worked for a local post office in Moradabad, UP) in order to purchase a small piece of land to cultivate bamboo-a crop that is comparatively easier to manage than others. During his entire life of 101 years, Maharshi Mehi received the income through shared cropping (after his passing in 1986, the income has continued to be received by the community of monks). Even though his sannyasin followers often do not have a way to earn income, Maharshi Mehi emphasized that they contribute to all tasks of äśrams, including preparing food, receiving guests, cleanliness along with the strict regimen of daily meditation, reading, prayers, etc. As a sant, Mehi questioned the divide between the teachings of Sant tradition and Sanātana Dharma. Avoiding the term Hinduism, he utilized the terms "Vedic Dharma" and "Sanātana Dharma." Similar to those earlier sants, he further initiated people of all social strata in his tradition and presented a model community that was organized by the shared vision of the attainment of higher spiritual states through meditation, not on the basis of caste or ritual.

What is unique about Maharshi Mehi is that he methodically demonstrated the roots of the Sant teachings in the ancient scriptures of Sanātana Dharma in his compendium, Satsang Yoga. By providing texts from the Vedas to modern sant traditions, he challenged those views that situate Sant traditions outside of Sanātana Dharma. In his article, Singh (2013) writes about Maharshi's efforts to prove the unity between Santmat and Sanātana Dharma. Maharshi Mehi's compositions, including Ved Darshan Yoga (the Philosophy of Vedas), Shri Gita Yoga Prakash (the Light of Gita Yoga), and Ramcharit Manas Sar Sateek (The Essence of Ramcharit Manas), aim to render the essence of these texts consistent with the principles of Santmat (guru, dhyān, satsang, and sadācar) in an accessible 
language. Likewise, his writings emphasize the nirguna (attribute-less) form of the Divine, but did not reject saguna bhakti (meditation on guru) as a means to reach the nirguna. Maharshi Mehi also composed a compendium of verses Padavali, which are reminiscent of medieval sant poetry. Men and women sing these verses in their daily practice.

I suggest that by virtue of his renunciation and remaining on the periphery of dogmatic Hinduism, Maharshi Mehi confronted scholars' presupposition concerning the rift between Sant-Mat and Hindu Dharma. He made available the esoteric teachings of Upanișad-generally confined to Sanskrit-speaking intellectuals and holy men and women-to non-literate masses through Hindi translations of texts and delivering discourses in regional languages of Bihar and West Bengal. At the same time, challenging the emerging dogmatic tendencies among various sant traditions, he established that Santmat's ideas are in unison with the mystical teachings of Sanātana Dharma. Although Santmat, like other bhakti sants, elevated "the householder life to equal status of that of the sannyāsi as far as the possibility of achieving the supreme state of the beatific vision," its leadership of sannyāsis has allowed for the creation of a space in which the path of Santmat and vernacular practices can co-exist (cf. White 1988). In the practice of monasticism, the interface between Santmat and Sanātana Dharma become more visible. The monasticism of Santmat constitutes a hybrid form of both śramānaic traditions (Buddhist and Jain) and the influence of the Upanișads. Even as the gurus challenge superstitions and hierarchies, they embrace many concepts and praxes found in Vedic Dharma, giving rise to a tradition that I have termed "Vernacular Vedic Dharma."

\section{Santmat tradition: constructing vernacular Vedic dharma}

Even though Santmat does not, in theory, discriminate along the lines of caste, religion, and status, the tradition does not reject family customs and rituals, as Rādhāsoāmi and other sects do. In Santmat's rendering of Vedic Dharma, parallel religiosities of universal inner meditation experiences and regional ritual practices are harmonized. In practice, while many devotees replace the worship of the icons of family deities with the photo of the Guru, others include both Guru and the deities on the same alter. However, meditation retreats bring the followers of various social and economic positions under one canopy, following the same daily routine of dhyāna and satsang. This ethnographic example demonstrates the weaving together of parallel religiosities under a single "canopy" whose structure is not static and boundaries are fluid. Gurus of the tradition hold monthly or weeklong meditation retreats where thousands of practitioners gather to meditate five times a day for one-hour sessions, beginning at three in the morning. ${ }^{26}$ These retreats place great emphasis on inner mystical experiences and this constant practice helps the practitioner to make progress. Such emphasis on the value of personal experiences is a testament to the experimental nature of Santmat. Many men and women report their inner experiences to the teacher, seeking private council. Such gatherings create a feeling of "communitas," to use Turner (1995) phrase: a community connected by the leadership of common Guru and the path. Since most villagers do not even speak Hindi, singing of bhajans (sacred songs) in the regional dialects supplements the literary analysis of Hindu texts, making both songs and texts accessible to rural people. Each afternoon there is a reading of the Rämāyana, which ends with ārtì (Hindu ritual of worship, or püja). The 
$\bar{a} r t \bar{l}$ does not incorporate the more typical püjā paraphernalia of lamp and incense, but rather is a sacred song in which the symbolic representation of the pūja $\bar{a}$ is sung. Symbolic representation of the ritual satisfies the tradition of ritual performance. At the same time, it invites the followers to experience the inner spiritual states represented by outer ritual. The devotees of Santmat, many of whom come from deep villages and have no formal education, have memorized the $\bar{a} r t \bar{t}$ and sing it every morning and evening as a part of the daily worship:

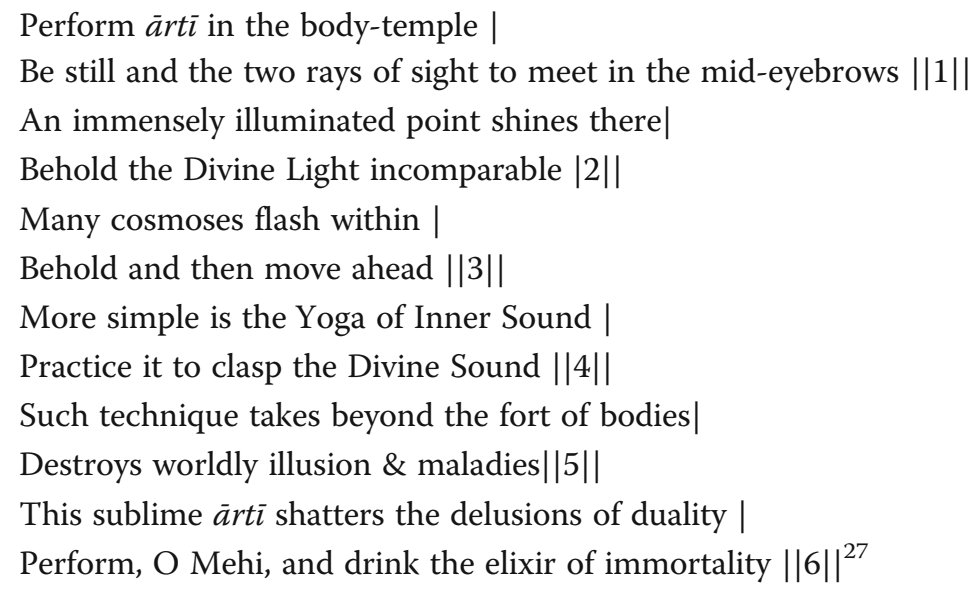

This $\bar{a} r t \bar{i}$ organizes and represents the entire path of Santmat in six short poetic verses. In the singing of the $\bar{a} r t \bar{i}$, the performative religiosity of Hindu ritual and Santmat's esoteric experience converge, inspiring the followers to practice the path in their daily lives.

The confluence of vernacular Hindu traditions and Santmat's principles is most visible in the annual gatherings of the tradition. Annual three-day satsangs-funded by meager contributions of thousands of devotees and donations of the few privileged followers-are held in massive tents outside the villages, typically on riverbanks, where thousands of followers congregate, meditate, and listen to spiritual discourses. This is reminiscent of Hindu melās, pilgrimages of faith, which traditionally are celebrations of communities of sādhus. It is intriguing to witness at three-thirty in the morning thousands of men and women, many of whom are extremely poor, sitting with erect backs and meditating together in tents. The long hours of meditation fall in line with the teachings of Maharshi Mehi, who emphasizes in his teachings that the time of death is uncertain; therefore, it is essential to meditate every day. These gatherings are similar to that of local religious festivals, yet they emphasize a structured routine of mediation, satsang, and bhajans. A massive decorated stage-evocative of a temple canopy-is created for the sages.

Many temple symbolism is incorporated into the spiritual path. For example, devotees bring flowers and sweets to offer to the Guru, who represents the living image of God; throngs of men, women, and children rush to touch the Guru's feet and seek blessings; and the sound of songs sung by women and men in their tribal dialects reverberate throughout the pandal (big tent). While the teachers do not put emphasis on supernatural powers, followers share the stories of miraculous powers of the Guru. These devotees consider the Guru to be the living embodiment of the Divine who leads them towards liberation and guides their conduct in this life. 
During the season of local religious festivals and after performing their family religious rituals, many devotees come to the Guru to offer gifts and seek blessings. Even teachers incorporate some of the indigenous Indian customs. For example, Maharshi Mehi was cremated according to Vedic rituals, accompanied by the singing of the songs of sants and all the ashram sädhus shaved their heads, a practice that continues in rural Hindu traditions. Maharshi Mehi's ashes were placed in a pot, which was set in a newly built Samadhi Mandir. Maharshi Mehi's syncretic practice of balancing indigenous and guru traditions is reflected in the practices of Santmat followers, who worship their deities along with the worship of the guru, practice rituals along with the meditation and satsang, and consult family astrologers along with council from the teachers.

In practice, Santmat followers also participate in communal meditations, meals, singing, and satsang. Santmat traces its roots to the Upanișads but claims not to be affiliated to any one religion, which seems contradictory. However, the tradition focuses on the Sanātana spirit of Hinduism ("Truth is One; the Sages speak of it in various ways") and emphasizes the underlying unity in the esoteric teachings of all religions. This unique feature attracts the followers of other religions, including Jainism, Islam, Christianity, and other traditions. However, in praxis only rituals that are associated with Hinduism have organically become incorporated. To that extent, Santmat of Bihar can be termed as "Vernacular Vedic Dharma."

\section{Santmat: Negotiating ideologies of individual spiritual attainment with community welfare}

The unique feature of the monastic movement of Santmat is that it brings reform to the people of rural and tribal areas immersed in orthodox customs of purity, gender biases, and even the performance of animal sacrifices due to the fear of deities. The renouncer gurus address both the spiritual and social wellbeing of their followers. In India's pre-colonial past, although the renouncer was viewed as the catalyst for progression of new ideas, conventionally, a mahātmā or sādhu was typically identified by his renunciation of worldly ties in the pursuit of ultimate freedom (moksa). This is the predominant vision of renouncers endorsed by many colonial writings and, to a large extent, featured in Brahmanical textual models of sannyāsa (cf. DeNapoli, Antoinette 2014a, 2014b). But renouncer-monastics like Maharshi Mehi and those within his lineage challenge this simplistic and detached view of sannyāsa. ${ }^{28}$

During the $20^{\text {th }}$ century (in which Maharshi Mehi assumed leadership of Santmat), religious and social reformers of India blamed the world-denying philosophy, so visibly represented by sādhus and sannyāsīs, for India's colonization. As Oman (1903): 275 has argued: "It is largely due to the subtle effects of the spirit of sadhuism upon the character of the people of India that the country is so easily governed by a handful of foreign officials and a few thousand white soldiers." The outsiders' colonial dominance and critiques of Indian culture and religious life engendered critical discourse among elite native Indians "toward their own traditions." Eventually, according to Narayan (1989); Bronkhorst (1998), indigenous response to foreign criticism during the colonial era led to a reinterpretation of the value of renunciation and a revolution in the role of the sädhus, "usher[ing] in the image of the socially involved renouncer." ${ }^{29}$ Mahatma Gandhi, contemporary of Mahrshi Mehi, appealed to sadhus to become more engaged in society. Although uniquely monastic, the concern for the total 
well-being of the followers is the hallmark of Santmat; therefore, Maharshi Mehi emphasized self-supporting, socially concerned industrious followers.

The following glimpse into the daily routine of a contemporary guru of Santmat, whom I visited in the remote hills of Dehradun, provides insight into the question of how the boundaries of renunciation and social concern are negotiated and expanded to include modern issues. Guru Maharaj's humble kutìr (dwelling), surrounded by trees, has a thatched roof and a mud floor washed with cow-dung, and no electric outlets or fixtures. The guru, a monk in ochre robes, sits on his wooden plank and gives audience (darśana) to the followers who sit on the ground. The followers are a mix of monks and lay men and women of various strata of Hindu society, from both cosmopolitan and rural areas. Tribal men and women descend from the hilltops to pay homage to the sant. The conversations primarily focus on the path and practice of the inner esoteric path of meditation, and they are strewn with stories from the Rammāyana and the medieval and contemporary sants' lives. I was told that these tribal people were engaged with animal sacrifices but now, through the teachings of Santmat, have become vegetarian and have stopped the tribal traditions of sacrifice. The guru gave gifts to the needy, while followers paid respect by touching his feet. The guru's openness in receiving followers highlights his dedication to community and social development, which the gurus must do in order to stay relevant in a rapidly changing India. Although he has chosen to live separate from society by virtue of his monastic lifestyle, he still provides guidance to all who wish to study and learn.

Despite the lack of consistent electricity in the ashram, the guru uses modern technology to maintain a connection to those who cannot seek him out in person. During our conversation, his cell phone rang with a melodious ringtone of a bhajan (a hymn celebrating devotion to the guru). The sant glanced at his followers with a smile and answered the phone. Since the phone was on speaker, it was easy to make out the voice and tone of the caller. Within an hour's time, he had received about three phone calls from men and women with various queries: some devotees in Bihari dialect asked for his blessings for specific occasions (starting first day of college, marriage of daughter). Others in literate Hindi called for consultation with serious predicaments (job loss, the conflict arising from a son's decision to marry a woman of a different caste). The guru patiently listened to the callers and told them to trust the will of the Supreme and to meditate on Sadguru Maharaj (he addresses his own guru in this way). The calm and serenity of the ashram's meditative environment was often interrupted by the ringtone of the bhajan summoning another query or problem from a devotee, who considers the guru's advice as a Divine command. By virtue of his persona of the $s \bar{a} d h u$, each day the guru negotiates the boundaries of sacred and secular problems as well as otherworldly profound discourses through his incorporation of technologies like cell phones.

The guru stands on the threshold of both the aspiration of spiritual attainments and concern for social needs. Kirin Narayan quotes anthropologist Veena Das, who also identifies this connection: "The sannyāsī does indeed appear to be in a permanent state of liminality, standing on the threshold between humans and deities, between caste society and the religious transcendence of society, between the living and the dead." ${ }^{30}$ The guru stands on the threshold of both Vedic Dharma and Sant tradition in praxis. Victor Turner defines liminal people as being ambiguous, who do not quite fit in the normative culture: "The attributes of liminality or liminal personae ('threshold people') 
are necessarily ambiguous, since this condition and these persons elude or slip through the network of classifications that normally locate states and positions in cultural space." ${ }^{31}$ It is a testament to the renouncer's liminality that he can transcend the structures of caste and class and is free to question and move beyond established norms and power structures (cf. Gross 1992).

The sädhu's monastic lifestyle and the locale of the ashram community form a "liminal group," to use Turner's (1995) language, which transcends the socially imposed structures of caste and gender. Turner says,

The liminal group is a community or comity of comrades and not a structure of hierarchically arrayed positions. This comradeship transcends distinctions of race, age, kinship position, and, in some kinds of cultic group, even of sex (Turner 1995, 100).

The "liminal" position of Santmat's gurus help them to experiment with the boundaries of Santmat and link it with Sanātana Dharma. Furthermore, the guru's authority as a spiritual leader makes it possible for him to create a space that facilitates experimentation in the dharma traditions of South Asia.

For instance, ashram visitors and inhabitants (men and women) are varied between those who fall in the Brahmin caste system and those with tribal backgrounds who are not raised in any caste structure. They sit together on the ground and share meals and participate together in dhyāna and satsang, forming a liminal group. In their shared vision, ashram dwellers created communitas with the principle, "Each for all, and all for each," as some ethnographers have phrased the experience. ${ }^{32}$ The followers of Santmat also embody a liminal state, as they stand between the boundaries of Santmat and Hindu dharmas. "Liminality" here makes explicit that there is a space, the "betwixt and between" space, where parallel religiosities come together in Santmat's unique interpretation of Vedic Dharma, not as separate religion, but as a source of wisdom of the path of Light and Sound. The scope of Santmat's outreach is vast: there are about a thousand ashrams of Santmat or spiritual centers all over India, primarily in rural areas. Both monks and laity of all castes, gender, and social status equally participate in satsang and dhyāna-illustrative of liminal space between Vedic Dharma and Sant traditions.

\section{Conclusion: the experimentation of Vedic Dharma}

The teachings and practices of Santmat analyzed here provide insight into the diverse nature of the sant traditions of Hinduism. Modern monastic Santmat draws upon the universal spirit of Sanātana Dharma, local religiosity, and the esoteric elements and reform of the Sant movement. Due to its experimental nature and its new interpretation of both Sanātana Dharma and Santmat, it can be termed as "Vernacular Vedic Dharma." With its millions of disciples, the modern Santmat of Bihar expresses a hybrid religiosity through its emphasis on lived practice and an experiential path. Santmat does not fit into the structures of either orthodox Hinduism or conventional sant traditions. Rather, it stands as a discrete movement that provides spiritual, social, and personal guidance to the most impoverished of the country by making use of a shared language of symbols and myths. Santmat takes pride in its identity as "Santmat" because it seeks to convey the unity of the teachings of all sants. It has given hope to 
the underprivileged and oppressed people living in the rural areas of Bihar, who previously remained out of the reach of reformers and spiritual teachers. Santmat's ideology and practices make it easy to incorporate principles of meditation, morality, and an allembracing attitude into the Hindu way of life.

The ethnographic example highlighted in the article in connection with the monastic Santmat movement prevalent in Bihar provides a context for thinking about the methods and processes of experimentation in contemporary religiosity. Santmat's unique monastic leadership indicates that liminality opens a space for experimentation in the construction of hybrid identities and, hence, new interpretation of Vedic Dharma. As the other contributors to this volume also suggest, the processes of experimental religion are similarly seen in the religious practices of various dharma communities within and outside of India, particularly when they encounter the concerns illustrative of modern times. However, modern Santmat monastics' novel modes of experimenting with the mystical philosophy of the Upanișads in the arena of lived vernacular dharmas of rural areas give new meaning to both Santmat and Sanātana Dharma. By emphasizing the credibility of the inner personal experiences of its practitioners, it situates the Sant tradition within Sanātana Dharma and simultaneously challenges the factional and extremist tendencies of some Hindu dharmas.

\section{Endnotes}

${ }^{1}$ The tradition traces its lineage to Sant Tulsi Sahib of Bihar. Lineage: Sant Tulsi Sahib of Hathras, Baba Devi Sahab of Moradabad, Maharshi Mehi Paramhans, Swami Santsevi Ji Maharaj, Swami Vyasanand Baba, and many sādhus who are teaching Santmat.

${ }^{2}$ In her article, "The Development of Sanātana Dharma in the Twentieth Century: A Rādhāsoamī guru's perspective," Diana Dimitrova (2007) provides a historical account of the new renderings of Sanātana Dharma in the twentieth century, including the Rādhāsoamīs guru, Paramdyaal Faqir Chand's appropriation of the concept of Sanātana Dharma. However, most Rādhāsoamī gurus isolated themselves from the texts and traditions of Vedic Dharma or Sanātana Dharma.

3"Vedic Dharma" and "Sanātana Dharma" are terms often used interchangeably to describe Hindu tradition. However, given Hinduism's increasing association with sectarian representation, some spiritual leaders prefer to avoid the term "Hinduism." These terms signify universal wisdom and enduring principles, not caste and ritual based traditions. The monastic Santmat movement embraces Vedic Dharma and Sānatana Dharma as the tradition containing the ancient path for attaining the union with the Divine.

${ }^{4}$ Just as the modern Santmat movement of Bihar experiments with the teachings of "Hindu Dharma" in order to render them relevant for the contemporary times, Rādhāsoamī and related branches of Santmat can be called "experimental Sikhism."

${ }^{5}$ Medieval sants utilized various ideologies of Hinduism, Islam, and folk traditions. Sant movements, like Rādhāsoamī are influenced by Sikh teachings.

${ }^{6}$ See also DeNapoli, Antoinette (2014b).

${ }^{7}$ See also Dumont (1973); Bhagat (1976); Bronkhorst (1993); Howard (2013).

${ }^{8}$ Dimitrova (2007) demonstrates how one guru of Rādhāsoamī movement sought to appropriate the concept of Sanātana Dharma. 
${ }^{9}$ See Juergensmeyer (1987), pp. 329-355.

${ }^{10}$ Ibid., 343

${ }^{11}$ In The Origins of Sant Mat Sach Khand (2015 Kindle Amazon), James Bean provides a comprehensive account of various lineages of Santmat traditions.

${ }^{12}$ Maharshi Mehi (1885-1986) was a disciple of Baba Devi Sahab of Moradabad, UP. It is believed that Baba Sahab (1841-1919) was born with the blessings of Sant Tulsi Sahab and that he considered Sant Tulsi Sahab his guru. Most contemporary Santmat movements trace their lineages to Sant Tulsi Sahab of Hatharas. Maharishi Mehi spread the teachings Santmat to the rural areas of Bihar, Nepal, and Uttar Pradesh. His life and teachings have been a subject of doctoral research projects in Bihar.

${ }^{13} \hat{S} \bar{a} n t i$ is a Sanskrit word with several English meanings such as "peace," "tranquility", "bliss," etc. The peace which results from some degree of Divine communion is śänti.

${ }^{14} \mathrm{~A}$ sant in the Santmat tradition is one who experiences Sat (Truth), the mystical state of divine union; it is a title conferred because of yogic achievements. A saint of the Santmat tradition is one who has achieved realization of the Divine, and, subsequently, his behavior is moral. Clearly, many Western saints also fall into the Santmat definition of saint. The words "sant" and "saint" are used interchangeably.

${ }^{15}$ Maharshi Mehi draws on select Upanișads in order to support this thesis. In his research on the path of yoga and the nature of atman and Brahman, he cites passages from the texts, including The Bhagavad-Gitā and Śvetașvatara Upanișad, and for his support for the path of Divine Light and Sound, he draws on the later Upanișads including from Nada Bindu Upanișads, Dhyānabindu Upanișad, and Śandilyopanșiad. He does not concern himself with the academic debates on the authority and authenticity of the earlier Upanișads.

${ }^{16}$ The seers of the Upanișads wrote in the Sanskrit language, which is not a language of the common people. According to Maharshi Mehi, Guru Nanak and Kabir Sahib elucidate the same Upanișadic wisdom in vernacular, a language understood by the common man.

${ }^{17}$ Maharshi Mehi, Moksha Darshan (Philosophy of Lliberation), translated by Veena Howard (1998).

${ }^{18}$ Surat Sabda (the Yoga of Divine Sound) is the practice of transcending the mind and entering the level beyond the mind, the level of Oneness. The vehicle for this inward journey is Sound. The way to employ Sound and to understand its use is the practical application of Surat Śabda Yoga. This is also known as Nadānusandāana (lit., "search of the divine sound").

${ }^{19}$ For example, even though Sant Kabir was non-sectarian, his tradition is named as Kabir Panth and Guru Nanak's teachings eventually led to the formation of Sikh Dharma.

${ }^{20}$ Maharshi Mehi (1998), p19-20. See Howard (1998) translation.

${ }^{21}$ See DeNapoli, Antoinette (2014a, 2014b) for another examination of the interface between non-literacy and memory in constructions of sādhu-sant communities as "scriptural."

${ }^{22}$ Personal Communications, Veena Howard.

${ }^{23} \mathrm{http}: / /$ www.spiritualawakeningradio.com/

${ }^{24}$ Primiano (2012), 382-394.

${ }^{25}$ See also DeNapoli in this volume. 
${ }^{26}$ The variety of regional diversity of practitioners is evident from the language they speak, including Hindi, Bihari, Avadhi, Nepalese, Bengali, Marwari, Gharvali, and many others.

${ }^{27}$ Maharshi Mehi, Maharshi Mehi Padavali (Verses of Maharishi Mehi). Translation is my own.

${ }^{28}$ See also the work of DeNapoli in this volume.

${ }^{29}$ Quoted from Veena Howard (2013), p. 134-135.

${ }^{30}$ Ibid., p. 136.

${ }^{31}$ Turner (1995), p. 95.

${ }^{32}$ As stated above, Turner concludes that much of the behavior of a group in "liminal" situations that has been recorded by ethnographers "falls under the principle: 'Each for all, and all for each.” Turner (1995), pp.100-101.

\begin{abstract}
Acknowledgments
This project was supported by 2016-2017 Chancellor's Office, California State University, Fresno, Research, Scholarship and Creative Activities Awards. This award helped me to dedicate my time to prepare the final draft of the manuscript for publication. I would also like to thank Professor Antoinette E. DeNapoli, Ph.D, University of Wyoming, and Professor Rita D. Sherma, Graduate Theological Union, Berkeley, CA, for their valuable feedback and suggestions for improving the article. I differentiate Santmat, the modern movement sant tradition of Bihar, from Sant-Mat, the medieval sant traditions of India, by using these distinct spellings throughout the article, even though they translate the same. Santmat is comprised of two words, sant and mat. The term sant is not equivalent to the term saint. In Hindu traditions sants are those who have experienced the truth (sat) and are considered as religious authority by the masses. Saints in Catholicism are individuals canonized by the church because their exceptional holiness. The term mat is generally translated as "way," "view," or even "religion" (more common in the regions of South India).
\end{abstract}

\title{
Competing interests
}

I confirm that I have read SpringerOpen's guidance on competing interests and I as the author has no competing interests in the manuscript.

\section{Publisher's Note}

Springer Nature remains neutral with regard to jurisdictional claims in published maps and institutional affiliations.

Received: 29 December 2016 Accepted: 27 April 2017

Published online: 10 July 2017

\section{References}

Bhagat, M.G. 1976. Ancient Indian asceticism. New Delhi: Motilal Banarsidass.

Bronkhorst, Johannes. 1998. Two sources on Indian asceticism. Delhi: Motilal Banarsidass.

DeNapoli, Antoinette. 2014a. Our own two hands create our destiny: narrative strategies and patterns in male sadhus' stories. Contrib Indian Sociol 48(3): 333-356.

DeNapoli, Antoinette. 2014b. Real sadhus sing to God: gender, asceticism, and vernacular religion in Rajasthan. Oxford: Oxford University Press.

Dimitrova, Diana. 2007. The development of Sanatana Dharma in the twentieth century. Int J Dharma Stud 11(1): 89-98.

Dumont, Louis. 1970. Religion, politics, and history in India: collected papers in Indian sociology. The Hauge: Mouton.

Gold, Daniel. 1987. Clan and lineage among the Sants: seeds, service, substance. In The Sants: studies in a devotional tradition of India, ed. Schomer Katherine and W.H. McLeod, 305-328. Berkeley: Berkeley Religious Studies Series.

Gross, Robert L. 1992. The sadhus of India: A study of Hindu asceticism. Jaipur: Rawat Publications. 2001.

Howard, Veena. 2013. Gandhi's ascetic activism: renunciation and social action. New York: State University of New York Press. Juergensmeyer, Mark. 1987. The Radhasoami revival of the Sant tradition. In The Sants: studies in a devotional tradition of India, ed. Schomer Katherine and W.H. McLeod, 338-342. Berkeley: Berkeley Religious Studies Series.

Levi-Strauss, Claude. 1966. The savage mind. Chicago: University of Chicago Press.

Lipner, Julius. 2010. Hindus: their religious beliefs and practices, 2nd ed. New York: Routledge.

Lorenzen, David N. 2011. Religious identities in Gorakhnath and Kabir: Hindus, Muslims, Yogis, and Sants. In Yogi heroes and poets, ed. Lorenzen David and Muñoz Adrián, 19-51. New York: State University of New York Press.

McGuire, Meredith. 2008. Lived religion: faith and practice in everyday life. New York: Oxford University Press.

Mehi, Maharshi. 1998. Mokșa-Darshan. English edition: 1998. The philosophy of liberation (trans. Veena Howard). Santmat Society of North America.

Narayan, Kirin. 1989. Storytellers, saints, and scoundrels: folk narrative in Hindu religious teaching. Philadelphia: University of Pennsylvania Press.

Oman, John Campbell. 1903. The mystics, ascetics, and saints of India: a study of Sadhuism, with an account of the yogis, sanyasis, bairagis, and other strange Hindu sectarians. London: T.F. Unwin.

Primiano, Leonard N. 2012. Afterword: manifestations of the religious vernacular: ambiquity, power, and creativity. In Vernacular religion: expressions of belief, ed. Bowman Marion and Valk Ulo, 382-394. Sheffield: Equinox Publishing. 
Primiano, Leonard N. 1993. Intrinsically Catholic: vernacular religion and Philadelphia's "dignity. http://repository.upenn. edu/dissertations/AA19331830/. Accessed 7 May 2017.

Schomer, Katherine, and W.H. McLeod. 1987. The Sants: studies in a devotional tradition of India. Berkeley: Berkeley Religious Studies Series.

Singh, Pravesh K. 2013. The bridge between Hindu scriptures and Santmat. https://medium.com/sant-mat-meditationand-spirituality/maharshi-mehi-the-bridge-between-hindu-scriptures-and-sant-mat-by-pravesh-k-singh2fadde15060d. Accessed 7 May 2017.

Turner, Victor. 1995. The ritual process: structure and anti-structure. Piscataway: Aldine Transactions.

White, Charles S.J. 1988. Indian developments: sainthood in Hinduism. In Sainthood: its manifestations in world religions, ed. Kieckhefer Richard and George D. Bond. Berkeley: University of California Press.

Submit your manuscript to a SpringerOpen ${ }^{\circ}$ journal and benefit from:

- Convenient online submission

- Rigorous peer review

- Immediate publication on acceptance

- Open access: articles freely available online

- High visibility within the field

- Retaining the copyright to your article

Submit your next manuscript at $>$ springeropen.com 